\title{
Does exercise capacity, dyspnea level, or quality of life actually predict mortality in patients with COPD? 8-year follow-up
}

\author{
Fatma ÇiFTÇi ${ }^{1}$ \\ Elif ŞEN ${ }^{1}$ \\ Öznur AKKOCA YILDIZ ${ }^{1}$ \\ Sevgi SARYAL ${ }^{1}$
}

${ }^{1}$ Department of Chest Diseases, Faculty of Medicine, Ankara University, Ankara, Turkey

${ }^{1}$ Ankara Üniversitesi Tıp Fakültesi, Göğüs Hastalıkları Anabilim Dalı, Ankara, Türkiye
Cite this arcticle as: Ciftçi F, Sen E, Akkoca Yıldız Ö, Saryal $S$. Does exercise capacity, dyspnea level, or quality of life actually predict mortality in patients with COPD? 8-year follow-up. Tuberk Toraks 2019;67(2):83-91.

\section{Yazışma Adresi (Address for Correspondence)}

\section{Dr. Fatma ÇiFTCi}

Ankara Üniversitesi Tıp Fakültesi, Göğüs Hastalıkları Anabilim Dalı, ANKARA - TÜRKIYE

e-mail: fatmarslann@yahoo.com

OCopyright 2019 by Tuberculosis and Thorax. Available on-line at www.tuberktoraks.org.com

\section{SUMMARY}

Does exercise capacity, dyspnea level, or quality of life actually predict mortality in patients with COPD? 8-year follow-up

Introduction: The goals of chronic obstructive pulmonary disease (COPD) treatment are to relieve dyspnea, increase exercise capacity, and improve quality of life. The relation of exercise capacity, dyspnea level, and quality of life with long-term mortality is unclear. Aim of the study was to assess the effect of exercise capacity, dyspnea level and quality of life on long-term mortality risk in patients with COPD.

Materials and Methods: Dyspnea level was assessed using the modified Medical Research Council (mMRC), Borg and Baseline Dyspnea Index (BDI) and Body Obstruction Dyspnea Exercise (BODE), health-related quality of life with St. George's Respiratory Questionnaire, and exercise capacity with the 6-minute walking test (6MWT) and cardiopulmonary exercise test. At the end of 8-year follow-up period, the relation between these tests and mortality was examined.

Results: A total of 42 patients with stable COPD were included in the study. Sixteen patients died during the approximately 8-year follow-up period. Univariate analysis revealed that $\mathrm{VO}_{2}$ peak [HR: 1.845; Cl: (1.336-2.55); $p<$ 0.001], BODE index [HR: 0.787; Cl: (0.703-0.880); $p<0.001]$, and SGRQ [HR: 1.073; Cl: (1.028-1.119); $p=0.001]$ were significantly correlated to mortality risk. Multivariate Cox regression analysis revealed $\mathrm{VO}_{2}$ peak [HR: 1.031; Cl: (0.683-1.120); $p=0.01]$ as the single significant predictor of mortality. $\mathrm{VO}_{2}$ peak less than 22.5 had a sensitivity of $82 \%$, specificity of $80 \%$, and area under the curve of 0.142 [95\% Cl: $(0.027-0.257) ; p<0.001]$ for mortality risk with ROC analysis.

Conclusion: Cardiopulmonary disturbances during maximal exercise may be an important indicator of mortality risk.

Key words: Chronic obstructive pulmonary disease; cardiopulmonary exercise test; 6-minute walking test; health-related quality of life; St. George's respiratory questionnaire 


\section{ÖZET}

\section{Egzersiz kapasitesi, dispne derecesi veya yaşam kalitesi KOAH hastalarında mortaliteyi yansıtır mı? 8-yıllık izlem}

Giriş: Kronik obstrüktif akciğer hastalı̆̆ı (KOAH)'nda tedavinin amacı dispneyi azaltmak, egzersiz kapasitesini ve yaşam kalitesini arttırmaktır. Egzersiz kapasitesi, dispne düzeyi ve yaşam kalitesi ile uzun dönem mortalite arasındaki ilişki belirsizdir. Bu araştırmanın amacı KOAH hastalarında egzersiz kapasitesi, dispne düzeyi ve yaşam kalitesinin uzun dönem mortalite riskini değerlendirmektir.

Materyal ve Metod: Dispne düzeyi "Değiştirilmiş Tıbbi Araştırma Konseyi" (modified Medical Research Council, mMRC), Borg ve Bazal Dispne Indeksi (BDI) ve Vücut Obstrüksiyonu Dispne Egzersizi (BODE), yaşam kalitesi St. George's Solunum Anketi ve egzersiz kapasitesi 6-dakika yürüme testi (6DYT) ve kardiyopulmoner egzersiz testi ile değerlendirildi. Sekiz-yıllık izlem süresinin sonunda bu testler ve mortalite arasındaki ilişki değerlendirildi.

Bulgular: Kırk iki stabil KOAH olgusu araştırmaya alındı. Sekiz-yıllık izlemde 16 hasta öldü. Tek değişkenli analizde pik $V \mathrm{O}_{2}[\mathrm{HR}$ : 1.845; CI: (1.336-2.55); $p<0.001], B O D E$ index [HR: 0.787; CI: (0.703-0.880); $p<0.001]$ ve SGRQ [HR: 1.073; Cl: (1.028-1.119); $p=0.001]$ mortalite riskiyle ilişkili bulundu. Çok değişkenli Cox regresyon analizine gore pik $\mathrm{VO}_{2}$ mortalitenin en anlamlı göstergesiydi [HR: 1.031; Cl: (0.683-1.120); $p=0.01]$. ROC analizinde pik $\mathrm{VO}_{2}<22.5$ değerinin \%82 duyarlılı, \%80 özgüllük ve 0.142 [95\% Cl: (0.027-0.257); $p<0.001]$ AUC değeriyle mortalite riskini gösterdiği saptandı.

Sonuç: Maksimal egzersiz sırasında ortaya çıkan kardiyopulmoner kısıtılıklar uzun dönem mortalite riskinin en önemli göstergesidir. Anahtar kelimeler: Kronik obstrüktif akciğer hastalığı; kardiyopulmoner egzersiz testi; 6-dakika yürüme testi; sağlık ilişkili yaşam

\section{INTRODUCTION}

Chronic obstructive pulmonary disease (COPD) is a common preventable and treatable disease characterized by persistent airflow limitation, which is usually progressive and associated with an enhanced chronic inflammatory response in the airways and lungs to noxious particles or gases. Exacerbations and comorbidities contribute to the overall disease severity in individual patients (1).

Mortality has been an important outcome in COPD, as it is currently the fourth leading cause of death in the world (2). The relationships of exercise capacity, dyspnea level and health status to mortality have rarely been evaluated.

The six-minute walking test (6MWT) is the most widely recognized test among time-based corridor walking tests. It is widely preferred becuse it is an easy, inexpensive, and practical method to determine submaximal exercise performance. It is used to assess treatment response after medical or surgical treatment or physiotherapy, to determine mortality and morbidity risk, and to determine functional capacity in lung disorders (3).

The cardiopulmonary exercise test (CPET) is considered the gold standard for the quantification of maximum exercise capacity in COPD. It is also used to reveal causes of exercise-limiting symptoms, to prescribe pulmonary rehabilitation programs, and to assess response to any treatment available (4). Respiratory questionnaires and dyspnea scales have been developed to rate the severity of respiratory difficulty, to detect differences between patients with low versus high levels of dyspnea, to evaluate changes in dyspnea level in paralel to disease progression, and to quantify the degree of respiratory difficulty. The modified Medical Research Council dyspnea scale (mMRC), Borg and Baseline Dyspnea Index (BDI) are used to rate dyspnea (5-7). The Body mass, airflow Obstruction, Dyspnea, Exercise capacity (BODE) index is a multidimensional test that uses body mass index (BMI), severity of airway obstruction, and walking distance, in addition to dyspnea severity as assessed using the mMRC (8).

Quality of life reflects the subjective thoughts about one's own health status. Disease or treatment modality alters quality of life by disrupting one's functional status, perceptions, and social status. The St. George's Respiratory Questionnaire (SGRQ) is a 76-item self-reported questionnaire composed of three categories, which assesses the impact of symptoms, activity, and disease on daily life (9).

Some of the goals of COPD treatment are to relieve dsypnea, increase exercise capacity, and improve quality of life. Dyspnea worsened by exertion causes a vicious cycle of reduced exercise capacity and impaired quality of life (10). Exercise tests have been developed to assess exercise capacity; however, it is still unclear how accurate they reflect dyspnea level and quality of life.

In the present study, we aimed to investigate the relation between exercise capacity and dyspnea grade, quality of life, and mortality after 8 years among patients with COPD. 


\section{MATERIALS and METHODS}

\section{Patients}

This prospective single-center study included 42 patients with stable COPD who were under follow-up at the COPD outpatient clinic. Four (9.5\%) patients were female and $38(90.5 \%)$ were male. COPD diagnosis was made on the basis of the Global Initiative for Chronic Obstructive Lung Disease (GOLD) criteria (11).

Patients older than 40 years of age who were stable and met the following criteria were included: meeting the COPD clinical diagnostic criteria (chronic dyspnea, cough, sputum expectoration), having air flow limitation according to the GOLD guidelines $\left(\mathrm{FEV}_{1} / \mathrm{FVC}\right.$ ratio $70 \%$ or below in spirometry), being able to perform the cardiopulmonary exercise test of sufficient duration and quality, and having no history of COPD exacerbations within the last 4 weeks.

The exclusion criteria were as follows: having acute myocardial infarction, unstable angina, symptomatic and hemodynamically unstable arrhythmias, active endocarditis, acute myocarditis or pericarditis, symptomatic severe aortic stenosis, uncontrolled decompensated heart failure, acute pulmonary embolism, pulmonary infarction, second- or third-degree heart block, orthopedic injuries precluding stress test, dissecting aortic and ventricular aneurysm, severe pulmonary hypertension (PAP $>40 \mathrm{mmHg}$ ), neurologic deficit, partial oxygen pressure below $50 \mathrm{mmHg}\left(\mathrm{PaO}_{2}\right.$ $<50 \mathrm{mmHg}$ ), partial carbondioxide pressure above 70 $\mathrm{mmHg}\left(\mathrm{PaCO}_{2}>70 \mathrm{mmHg}\right)$, and $\mathrm{FEV}_{1}$ below $30 \%$, acute exacerbation of COPD, non adherence with the study (mental and psychiatric disorders).

\section{Pulmonary Function Tests And Arterial Blood Gas Analysis}

Pulmonary function tests (expiratory air flow rates, static lung volumes, carbon monoxide diffusing testing) were performed. Expiratory flow rates and carbon monoxide diffusing capacity of the lung for were measured using a $V_{\max } 229$ Pulmonary Function/Cardiopulmonary Exercise Test (Sensormedics, Bilthoven, Netherlands).

Arterial blood gas samples were obtained through direct vascular puncture of the radial artery at rest, breathing room air. The samples were instantly studied using an ABL 90 Flex/Blood Gas Analyzer (Radiometer Ltd. Brønshøj, Denmark).

\section{Dyspnea Scores}

Disease stage was determined according to the

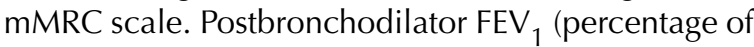
predicted) in respiratory function test, mMRC dyspnea scale value, BMI, and 6MWT (m) were used to calculate the BODE index. Functional impairment, magnitude of task and magnitude of effort-related dyspnea were measured, and the BDI score was calculated. Dyspnea severity was assessed using the Borg scale before and after 6MWT and CPET.

\section{Quality of Life}

Quality of life was rated using the SGRQ (9). A fixed-format self-complete 76-item questionnaire with three component scores [symptoms, activity, and impact (on daily life), and a total score] was administered to measure health in chronic airflow limitation.

\section{Six-Minute Walking Test}

The maximal walking distance $(\mathrm{m})$ at maximal pace along a 20-meter corridor for six minutes was recorded for patients during stable stage (12). The Borg scale was used to score dyspnea grade before and after exercise. Transcutaneous oxygen saturation, heart rate, and blood pressure were measured at the onset and the end of the test. No patient required a portable oxygen delivery system.

\section{Cardiopulmonary Exercise Test}

All subjects performed a symptom limited exercise test using bicycle ergometry (Ergometrics 900, SensorMedics ${ }^{\mathrm{TM}}$, Bilthoven, Netherlands). They performed incremental exercises by applying workloads that increased by 10-15-20 Watt/minute following a three-minute basal resting period and a three-minute warm-up period (13). During the test, all subjects were monitored to obtain their electrocardiogram, blood pressure, and oxygen saturation (Palce Pulse Oximeter $^{\mathrm{TM}}$ 53400, California, USA).

During the test, the following parameters were recorded at basal state, anaerobic treshold, and peak exercise; oxygen consumption $\left(\mathrm{VO}_{2}\right.$ peak), peak $\mathrm{CO}_{2}$ out-put $\left(\mathrm{VCO}_{2}\right)$, gas exchange ratio $\left(\mathrm{VCO}_{2} \mathrm{NO}_{2}\right)$, minute ventilation $(\mathrm{VE})$, peak heart rate $(\mathrm{HR})$, heart rate reserve (HRR), oxygen pulse $\left(\mathrm{VO}_{2} / \mathrm{HR}\right)$, peak workload (Wpeak) during the application of workload. The reason of the termination of the test (dyspnea or leg pain) was recorded. Pre- and post-test dyspnea grade were determined in compliance with 
the Borg scale. Since the patients reached $85 \%$ of the expected pulse rate, their tests were accepted as maximum and recorded.

\section{Follow-up Data}

Depending on the clinical indication, patients were followed up for 3- or 6-month periods between 2008-2017, approximately 8 years. In follow-up visits, symptoms of patients, dyspnea score of mMRC, pulmonary function tests were recorded. Patients who did not attend follow-up visits were called via the telephone and any missing information was obtained. This study was approved by University Clinical Research Ethics Committee (Registration number: 06-129-07). All procedures in this study followed were in accordance with the Helsinki Declaration of 1975, as revised in 2008. Informed consent was obtained from all patients for being included in the study.

\section{Statistical Analysis}

Statistical analyses were performed using the Statistical Package for Social Sciences (SPSS, Inc. Chicago, IL, USA 20) software package. Data distribution was tested with the Shapiro-Wilk test. The descriptive statistics included mean \pm standard deviation for normally distributed variables, median (range) for non-normally distributed variables, and number (percentage) for nominal variables. Statistical significance was set at $p<0.05$.

The linear correlation between two variables was analyzed using Pearson's or Spearman's corrrelation tests, depending on the normality of distribution. The survival status of the study group after 8 years was determined with life table and Kaplan-Meier survival analysis. Univariate analysis was used to find individual variables predicting mortality; multivariate Cox proportional hazard model regression analysis was used to determine independent variables predicting mortality. Receiver operating characteristics (ROC) analysis was performed to determine the optimal cutoff values for $\mathrm{VO}_{2}$ peak and to find the area under the curve (AUC), and specificity and sensitivity of $\mathrm{VO}_{2}$ peak.

\section{RESULTS}

The study included 42 patients with stable COPD. The mean age of the study population was $63.36 \pm$ 6.95 years and postbronchodilator $\mathrm{FEV}_{1}$ was $53.46 \pm$ 14.41 percentage $(\%)$ predicted. The general charac- teristics of the study population are shown on Table 1. The mean walking distance in the 6MWT was $450.34 \pm 71.62 \mathrm{~m}$. In the CPET, the mean Wpeak was $95.49 \pm 34.57$ watt and $\mathrm{VO}_{2}$ peak was $1.32 \pm 0.47 \mathrm{~L} /$ min (Table 2).

Sixteen patients died before the end of an approximately 8-year follow-up period. The cause of death was COPD or COPD-related disease in 10 patients, cardiac disorders in four, and malignancy and pulmonary thromboembolism in one patient each.

The mean follow-up duration of the study group was $6.4 \pm 2.4$ years. The time to mortality was $3.81 \pm 2.04$ years.

Univariate analysis showed that $\mathrm{VO}_{2}$ peak [HR: 1.845; Cl: (1.336-2.55); $\mathrm{p}<$ 0.001], BODE [HR: $0.787 ; \mathrm{Cl}:(0.703-0.880) ; \mathrm{p}<0.001]$, and SGRQ [HR: 1.073; Cl: (1.028-1.119); $p=0.001]$ increased mortality risk (Table 3 ). There was no significant relation between 6MWT and mortality.

Cox proportional hazard model analysis was used to determine the relative risk of death with different variables $\left(\mathrm{VO}_{2}\right.$ peak, BODE, 6MWT, SGRQ total score) (Table 3). According to that analysis, $\mathrm{VO}_{2}$ peak [HR: $1.031 ; \mathrm{Cl}:(0.683-1.120) ; \mathrm{p}=0.01]$ significantly increased the risk of death, but BODE [HR: $0.978 ; \mathrm{Cl}$ : (0.571-1.626); $p>0.05]$ and SGRQ [HR: 0.827; Cl: $(0.976-1.090) ; p>0.05]$ were not predictive of mor-

Table 1. General characteristics of the study subjects

Patients with COPD

$\begin{array}{lc}\text { Subjects, N } & 42 \\ \text { Age, years } & 62.45 \pm 8.22 \\ \text { Sex, Male } & 38(90.5) \\ \text { BMI, kg/m }{ }^{2} & 22.12 \pm 3.13 \\ \text { Smoking, pack/years } & 40.12 \pm 17.32 \\ \text { FEV }_{1}, \% \text { pred } & 53.46 \pm 14.41 \\ \text { FVC, \% pred } & 79.31 \pm 24.16 \\ \text { FEV } 1 \text { /FVC } & 48.24 \pm 9.32 \\ \text { mMRC } & 2.24 \pm 0.93 \\ \text { BODE } & 2.17 \pm 1.23 \\ \text { BDI } & 8.11 \pm 4.25 \\ \text { SGRQ, total } & 51.05 \pm 28.34 \\ \text { SGRQ, symptom } & 58.31 \pm 19.33 \\ \text { SGRQ, activity } & 73.17 \pm 11.21 \\ \text { SGRQ, impact } & 41.4 \pm 16.7\end{array}$


tality. A multivariate Cox regression analysis of variables revealed that a significant predictor of mortality was $\mathrm{VO}_{2}$ peak.

ROC analysis for $\mathrm{VO}_{2}$ peak was performed (Figure 1). $\mathrm{VO}_{2}$ peak (pred \%) less than 22.5 had a sensitivity of $82 \%$, specificity of $80 \%$ and an AUC of 0.858 [95\% Cl: (0.743-0.973); $\mathrm{p}<0.001]$ for mortality risk. Kaplan-Meier cumulative survival analysis demon-

Table 2. 6MWT and CPET parameters of the study group

\begin{tabular}{|l}
\hline Exercise test parame \\
\hline 6MWT \\
$6 \mathrm{MWT}, \mathrm{m}$ \\
Baseline $\mathrm{SpO}_{2}, \%$ \\
Final $\mathrm{SpO}_{2}, \%$ \\
Desaturation, \% \\
Baseline borg \\
Final borg \\
\hline
\end{tabular}

Patients with COPD $n=42$

\section{CPET (peak exercise)}

Wpeak, watt

$\mathrm{VO} 2, \mathrm{~L} / \mathrm{min}$

VO2, pred \%

$\mathrm{VO} 2 / \mathrm{kg}, \mathrm{mL} / \mathrm{kg} / \mathrm{min}$

$\mathrm{VO} 2 / \mathrm{kg}$, pred \%

VCO2, L/min

$\mathrm{BR}$

$\mathrm{VE}, \mathrm{L} / \mathrm{min}$

VE/NO2

VE/VCO2

$\mathrm{O} 2$ pulse, $\mathrm{mL} /$ beat

HRR, beats/min

Baseline SpO2, \%

Final SpO2, \%

Desaturation, \%

Baseline borg

Final borg

$$
\begin{gathered}
450.34 \pm 71.62 \\
91.32 \pm 4.21 \\
85.42 \pm 6.54 \\
6.72 \pm 3.43 \\
2.56 \pm 1.22 \\
4.81 \pm 2.35
\end{gathered}
$$

$95.49 \pm 34.57$

$1.32 \pm 0.47$

$49.84 \pm 14.35$

$16.40 \pm 4.87$

$59.06 \pm 15.09$

$1.58 \pm 0.51$

$0.34 \pm 0.14$

$44.98 \pm 16.12$

$33.15 \pm 7.98$

$32.67 \pm 8.07$

$8.66 \pm 4.10$

$46.92 \pm 21.13$

$91.32 \pm 4.21$

$85.42 \pm 6.54$

$6.72 \pm 3.43$

$2.56 \pm 1.22$

$4.81 \pm 2.35$ strated significantly higher survival rates of the $\mathrm{VO}_{2}$ peak $\geq 22.5$ group than $\mathrm{VO}_{2}$ peak $<22.5$ study groups during the 8 -year follow-up $(p<0.01)$. KaplanMeier survival curves based on $\mathrm{VO}_{2}$ peak groups are presented in Figure 2.

There was no significant correlation between the 6MWT and dyspnea scales and total $(r=-0.036)$, impact $(r=-0.027)$, symptom $(r=-0.102)$, and activity scores $(r=-0.062)$ of SGRQ questionnaire. Among CPET parameters, $\mathrm{VO}_{2}$ peak was correlated to SGRQ symptom score $(r=-0.382, p=0.03)$, activity score $(r=$ -0.440, $p=0.01)$, impact score $(r=-0.395, p=0.03)$, and total score $(r=-0.481, p=0.01)$ (Figure 3$). \mathrm{O}_{2}$ pulse was correlated to SGRQ symptom score ( $r=$

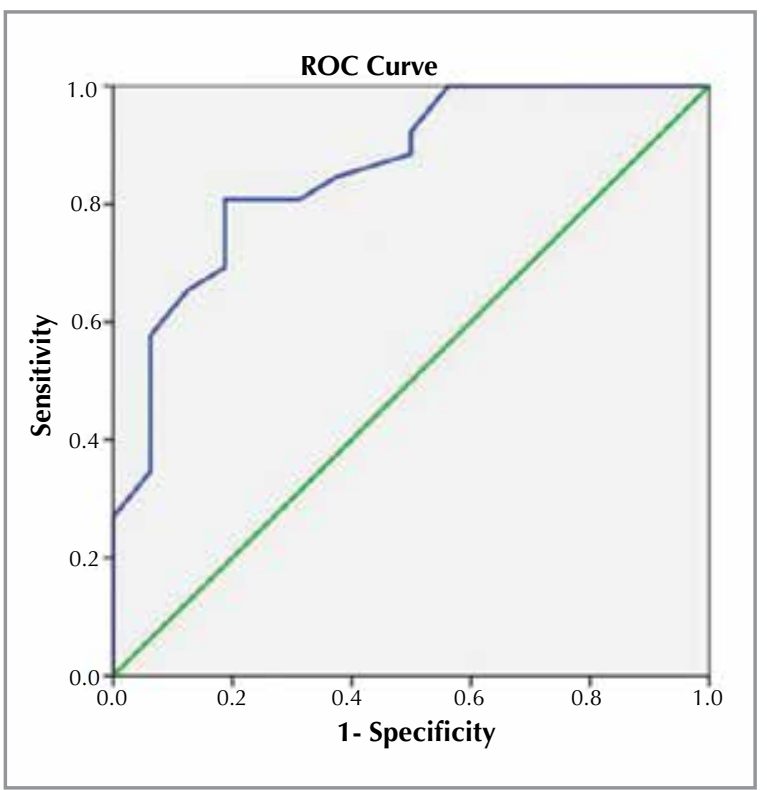

Figure 1. Receiver-operating characteristic (ROC) analysis for $\mathrm{VO}_{2}$ peak. $\mathrm{VO}_{2}$ peak (pred \%) greater than 22.5 had a sensitivity of $82 \%$, specificity of $80 \%$ and an AUC of 0.858 [95\% Cl: (0.743-0.973); $\mathrm{p}<0.001]$ for mortality risk.

Table 3. Univariate and multivariate Cox proprortional hazards analyses on the relationship between major clinical measurements and all-cause mortality

\begin{tabular}{|lccccccc|}
\hline Variable & \multicolumn{3}{c}{ Univariate Analysis } & \multicolumn{3}{c|}{ Multivariate Analysis } \\
\hline & $\mathbf{H R}$ & $\mathbf{9 5} \% \mathbf{C l}$ & $\mathbf{p}$ & & $\mathbf{H R}$ & $\mathbf{9 5} \% \mathbf{~ C l}$ & $\mathbf{p}$ \\
${$\cline { 2 - 5 }$}{ }_{2}$ peak $}$ & 1.845 & $1.336-2.55$ & $<0.001$ & & 1.031 & $0.683-1.120$ & 0.01 \\
BODE & 0.787 & $0.703-0.88$ & $<0.001$ & & 0.978 & $0.571-1.626$ & NS \\
SGRQ & 1.073 & $1.028-1.119$ & 0.001 & & 0.827 & $0.976-1.090$ & NS \\
6MWT & 0.410 & $0.129-0.490$ & NS & & 0.350 & $0.165-0.340$ & NS \\
\hline
\end{tabular}




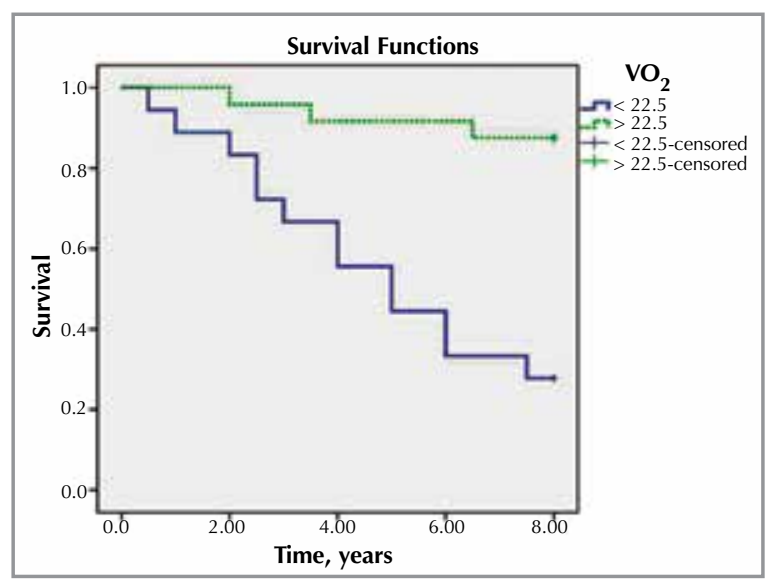

Figure 2. Kaplan-Meier cumulative survival plots demonstrating significantly higher survival rates of the $\mathrm{VO}_{2}$ peak $\geq 22.5$ study groups than $\mathrm{VO}_{2}$ peak $<22.5$ study groups during the 8-year follow-up $(p<0.01)$.

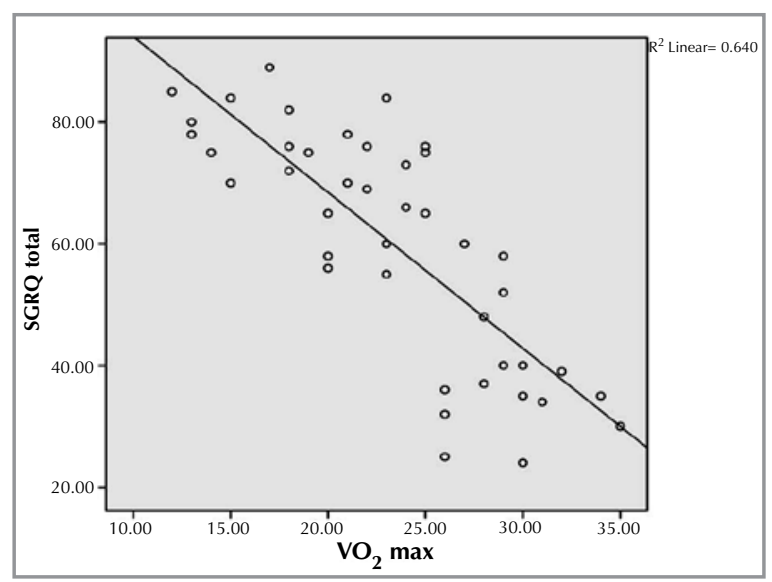

Figure 3. Scatterplot showing significant negative correlation between $\mathrm{VO}_{2}$ peak and SGRQ total score.

-0.458, $p=0.02)$, activity score $(r=-0.470, p=0.01)$, impact score $(r=-0.497, p=0.01)$, and total score $(r=$ -0.510, $\mathrm{p}=0.01)$.

There was a negative correlation between the BODE index and $\mathrm{VO}_{2}$ peak $(r=-0.423, p=0.02)$, $\mathrm{VE}(\mathrm{r}=$ -0.388, $\mathrm{p}=0.03)$, and $\mathrm{O}_{2}$ pulse $(r=-0.378, \mathrm{p}=0.03)$ (Table 4).

\section{DISCUSSION}

We evaluated factors related to mortality in COPD, particularly the relationships of exercise capacity, dyspnea level, and health-related quality of life to mortality and found that exercise capacity was the best independent predictor of mortality in patients with COPD.
Patients with COPD have a reduced exercise capacity and quality of life. Dyspnea is the main factor limiting exercise performance, mainly by preventing patients from attaining their maximum exercise capacity (13). Assessment of functional capacity has gained importance in attempts to fully understand the pathogenesis COPD. Exercise capacity of COPD patients is affected by complex factors, including ventilation, muscular function, gas excahange, circulation, nutritional status and dyspnea. Exercise capacity may thus evaluate the severity of COPD more comprehensively than airflow limitation. Peak $\mathrm{VO}_{2}$ is the primary measure of exercise capacity. The predictor of mortality during an 8-year follow-up of patients with stable COPD were $\mathrm{VO}_{2}$ peak and SGRQdetermined quality of life with univariate cox proportional hazard analysis. When SGRQ, BODE and $\mathrm{VO}_{2}$ peak were evaluated in multivariate analysis, the peak $\mathrm{VO}_{2}$ was the statistically the most significant independent risk factor in determining the mortality risk.

Waschki et al., in a prospective cohort study of 170 outpatients with stable COPD, demonstrated that objectively measured physical activity was the strongest predictor of all-cause mortality in patients with COPD (14).

In the present study, the association between quality of life and mortality was confirmed in univariate analysis. In a multivariate model, $\mathrm{VO}_{2}$ peak, which is probably the most reliable available index of exercise capacity, was associated with mortality risk. Yoshimura et al. suggested that peak oxygen uptake was preferable in order to investigate the relationship between mortality and COPD because it was more significantly correlated to mortality than any of the other variables (15). Similar results were obtained by Oga et al. and Hiraga et al. with exercise capacity being the most significant predictors of mortality $(16,17)$.

The 6MWT was not found to affect the prognosis of patients with COPD. Most of the disunity in the 6MWT in patients with COPD can be explained by factors that variably reflect the cardiac, respiratory, and metabolic determinants of physical performance (18). Furthermore, the walking distance may be affected by patient motivation and other subjective factors (19). 
Table 4. Correlation between six-minute walking test and cardiopulmonary exercise test parameters and respiratory function, dyspnea indexes, and quality of life questionnaire

\begin{tabular}{|c|c|c|c|c|c|c|c|c|c|}
\hline \multirow[b]{2}{*}{ Parameters } & \multicolumn{9}{|c|}{ CPET } \\
\hline & $\begin{array}{c}\text { 6MWT } \\
\mathrm{m}\end{array}$ & $\begin{array}{c}\text { Wmax } \\
\text { Watt }\end{array}$ & $\begin{array}{c}\mathrm{VO}_{2} \\
\mathrm{~L} / \mathrm{min}\end{array}$ & $\begin{array}{c}\mathrm{VO}_{2} / \mathbf{k g} \\
\mathrm{mL} / \mathbf{k g} / \mathrm{min}\end{array}$ & $\begin{array}{l}\mathrm{VCO}_{2} \\
\mathrm{~L} / \mathrm{min}\end{array}$ & $\begin{array}{c}\mathrm{VE} \\
\mathrm{L} / \mathrm{min}\end{array}$ & $\mathrm{VE} / \mathrm{VO}_{2}$ & $\mathrm{VE} / \mathrm{VCO}_{2}$ & $\mathrm{O}_{2}$ pulse \\
\hline $6 \mathrm{MWT}, \mathrm{m}$ & & $0.442^{*}$ & $0.501^{* *}$ & $0.401^{*}$ & $0.577^{* *}$ & $0.597 * *$ & -0.086 & -0.038 & 0.217 \\
\hline $\mathrm{FEV}_{1}, \%$ pred & 0.206 & $0.534^{* *}$ & $0.626^{* *}$ & $0.459^{* *}$ & $0.535^{* *}$ & $0.524^{* *}$ & -0.014 & -0.028 & 0.057 \\
\hline DLCO, \%pred & 0.059 & 0.286 & $0.455^{*}$ & 0.190 & $-0.377^{*}$ & 0.360 & $0.565^{* *}$ & $0.369^{*}$ & $0.401 *$ \\
\hline $\mathrm{mMRC}$ & -0.055 & 0.032 & -0.195 & -0.117 & -0.004 & -0.078 & 0.072 & -0.135 & -0.358 \\
\hline BODE & $-0.384^{*}$ & -0.227 & $-0.423^{*}$ & -0.118 & -0.323 & $-0.388^{*}$ & -0.082 & 0.088 & $-0.378^{*}$ \\
\hline BDI & -0.145 & -0.120 & -0.230 & -0.045 & -0.158 & -0.103 & -0.087 & -0.046 & -0.237 \\
\hline 6MWT baseline borg & 0.169 & 0.122 & 0.208 & 0.101 & 0.244 & 0.075 & 0.051 & -0.139 & 0.115 \\
\hline $6 \mathrm{MWT}$ final borg & 0.181 & 0.223 & 0.243 & 0.165 & 0.284 & 0.108 & 0.094 & -0.251 & 0.127 \\
\hline CPET baseline borg & 0.239 & 0.147 & 0.259 & 0.198 & 0.262 & 0.124 & 0.105 & -0.167 & 0.121 \\
\hline CPET final borg & 0.267 & 0.135 & 0.256 & 0.273 & 0.293 & 0.217 & 0.173 & -0.272 & 0.148 \\
\hline SGRQ symptom & -0.102 & -0.029 & $-0.382 *$ & -0.143 & -0.155 & -0.159 & 0.095 & 0.065 & $-0.458^{*}$ \\
\hline SGRQ activity & 0.062 & -0.180 & $-0.440^{*}$ & -0.140 & -0.221 & -0.117 & -0016 & 0.011 & $-0.47^{*}$ \\
\hline SGRQ impact & -0.027 & -0.109 & $-0.395^{*}$ & -0.134 & -0.216 & -0.098 & 0.102 & 0.073 & $-0.497^{*}$ \\
\hline SGRQ total & -0.036 & -0.149 & $-0.481 *$ & -0.160 & -0.271 & -0.161 & 0.052 & 0.059 & $-0.51^{*}$ \\
\hline
\end{tabular}

Antonelli-Incalzi et al. found a stronger association between the SGRQ score and mortality [HR: 1.61; 95\% Cl: (0.91-2.81)]. The association between the SGRQ and mortality attributed to non-pulmonary causes was similar to the one found for total mortality [HR:1.19; 95\% Cl: (0.99-1.44)] (20). The main finding of their study was that worsening $H R Q L$, as assessed using the SGRQ, was associated with increased mortality in an older population with COPD. Quality of life rated using the SGRQ (especially the impact subscale), helps to identify older patients with COPD at greater risk of death. Domingo-Salvany et al. concluded that SGRQ total and SF-36 physical summary scores were independently associated with total and respiratory mortality in Cox models (21).

Exercise tests instead of static tests are used to rate dyspnea in daily life. In the present study, a significant correlation was found between the two exercise tests among patients with COPD during a stable phase. It was noted that both exercise tests more accurately reflected multidimensional dyspnea level as assessed using BODE. CPET showed significant correlations with all SGRQ domains.

Conflicting results have been obtained by studies investigating the relation between 6MWT and BDI.
Our study failed to show any correlation between both exercise tests and $\mathrm{mMRC}, \mathrm{BDI}$, and pre- and post-exercise Borg dyspnea index. Pelegrino et al. studied 68 patients with COPD and failed to show any correlation between MRC or BDI and the 6MWT (22). On the other hand, Oga et al. showed a weak correlation between BDI and $\mathrm{VO}_{2}$ peak (19).

Submaximal and maximal exercise tests may not reflect dyspnea severity during daily life activities. Dyspnea is a subjective symptom that occurs in association with various physiologic and psychological factors (23). Thus, rating dyspnea that occurs during daily life activities is a more accurate method to evaluate the impact of COPD (24). The general view is that self-reported dyspnea rated using the Borg scale during exercise is often poorly reproducible. Moreover, it is difficult to ascertain which dyspnea factor is the primary one in COPD, because dyspnea mechanisms are complex and intertwined (25).

In this study, the BODE index, which is a composite dyspnea index that contains the 6MWT as a parameter, was inversely correlated with the $6 \mathrm{MWT}$ and $\mathrm{VO}_{2}$ peak. The BODE index, a multidimensional scale assessing several factors related to COPD, evaluates a surrogate of nutritional state (BMI), airflow obstruc- 
tion $\left(\mathrm{FEV}_{1}\right)$, dyspnea $(\mathrm{mMRC})$, and exercise capacity $(6 \mathrm{MWT})$, and may be a more accurate measure of COPD severity $(26,27)$. The number of studies assessing the association between different exercise tests and quality of life is quite limited (28). Studies have frequently used the 6MWT as the exercise test and SGRQ as the quality of life test. Even studies showing a positive correlation between 6MWT and SGRQ have revealed weak correlations between the SGRQ total and SGRQ activity $(29,30)$.

Our study showed no significant correlation between 6MWT and SGRQ scores, but it revealed a significant correlation between SGRQ's symptom, activity, and impact domains, and $\mathrm{VO}_{2}$ peak measured by CPET. This significant negative correlation indicates an improved health status with increased exercise performance and reduced SGRQ score. In support of similar studies, our study showed that CPET reflects quality of life more accurately than 6MWT $(30,31)$.

Our study has some limitations including its single-center design and the small number of subjects who were mostly male. The lower number of women is probably related to the lower prevalence of COPD among women in our country.

\section{DISCUSSION}

This study demonstrated significant relationships of exercise capacity and quality of life to mortality in patients with COPD. Furthermore, cardiopulmonary disturbances during exercise could be the most important predictors of prognosis. Exercise performance as determined using CPET reflects dyspnea and quality of life more accurately. We concluded that the pathophysiologic mechanisms that primarily affect quality of life in COPD might be ideally detected by cardiopulmonary exercise testing.

\section{CONFLICT of INTEREST}

All authors have no conflict of interests.

\section{AUTHORSHIP CONTRIBUTIONS}

Concept/Design: All of authors.

Analysis/Interpretation: All of authors.

Data Acquisition: All of authors.

Writting: All of authors.

Critical Revision: All of authors.

Final Approval: All of authors.

\section{REFERENCES}

1. From the global strategy for the diagnosis, management and prevention of COPD, Global Initiative for Chronic Obstructive Lung Disease (GOLD) 2017. Available from: http://goldcopd.org/

2. Criner GJ, Bourbeau J, Diekemper RL, Ouellette DR, Goodridge D, Hernandez $P$, et al. Prevention of acute exacerbations of COPD: American College of Chest Physicians and Canadian Thoracic Society Guideline. Chest 2015; 147:894-942.

3. ATS Committee on Proficiency Standards for Clinical Pulmonary Function Laboratories. ATS statement: guidelines for the six-minute walk test. Am J Respir Crit Care Med 2002; 166:111-7.

4. ATS. ATS/ACCP Statement on cardiopulmonary exercise testing. Am J Respir Crit Care Med 2003;167:211-77.

5. Bestall JC, Paul EA, Garrod R, Garnham R, Jones PW, Wedzicha JA. Usefulness of the Medical Research Council (MRC) dyspnoea scale as a measure of disabilityin patients with chronic obstructive pulmonary disease. Thorax 1999;54:581-6.

6. Borg GA. Psychophysical bases of perceived exertion. Med Sci Sports Exerc 1982; 14:377-81.

7. Mahler DA, Weinberg DH, Wells CK, Feinstein AR. The measurement of dyspnea. Contents, interobserver agreement, and physiologic correlates of two new clinical indexes. Chest 1984;85:751-8.

8. Celli BR, Cote CG, Marin JM, Casanova C, Montes de Oca $M$, Mendez RA, et al. The body-mass index, airflow obstruction, dyspnea, and exercise capacity index in COPD. N Engl I Med 2004;350:1005-12.

9. Jones PW, Quirk FH, Baveystock CM. The St George's Respiratory Questionnaire. Respir Med 1991;85:25-31.

10. Casaburi R. Activity promotion: a paradigm shift for chronic obstructive pulmonary disease therapeutics. Proc Am Thorac Soc 2011;8:334-7.

11. Rabe KF, Hurd S, Anzueto A, Barnes PJ, Buist SA, Calverley $P$, et al. Global Initiative for Chronic Obstructive Lung Disease. Global strategy for the diagnosis, management, and prevention of chronic obstructive pulmonary disease: GOLD executive summary. Am / Respir Crit Care Med 2007; 176:532-55.

12. ATS Committee on Proficiency Standards for Clinical Pulmonary Function Laboratories: ATS statement: guidelines for the six-minute walk test. Am J Respir Crit Care Med 2002;166:111-7.

13. Wasserman K, Hansen JE, Sue DY, Casaburi R, Whipp BJ. Principles of Exercise Testing and Interpretation. Third Edition p:130-2.

14. Waschki B, Kirsten A, Holz O, Müller KC, Meyer T, Watz $H$, et al. Physical activity is the strongest predictor of allcause mortality in patients with COPD: a prospective cohort study. Chest 2011;140:331-342. 
15. Yoshimura K, Maekura R, Hiraga T, Miki K, Kitada S, Miki $M$, et al. Identification of three exercise-induced mortality risk factors in patients with COPD. COPD 2014;11:61526 .

16. Oga T, Nishimura K, Tsukino M, Sato S, Hajiro T. Analysis of the factors related to mortality in chronic obstructive pulmonary disease/role of exercise capacity and health status. Am J Respir Crit Care Med 2003;167:544-9.

17. Hiraga $T$, Maekura R, Okuda Y, Okamoto T, Hirotani A, Kitada $S$, et al. Prognostic predictors for survival in patients with COPD using cardiopulmonary exercise testing. Clin Physiol Funct Imaging 2003;23:324-31.

18. Van Stel HF, Bogaard IM, Rijssenbeek-Nouwens $L H$, Colland VT. Multivariable assessment of the 6-min walking test in patients with chronic obstructive pulmonary disease. Am J Respir Crit Care Med 2001;163:1567-71.

19. Oga $T$, Nishimura $K$, Tsukino $M$, Hajiro $T$, Mishima M. Dyspnoea with activities of daily living versus peak dyspnoea during exercise in male patients with COPD. Respir Med 2006;100:965-71.

20. Antonelli-Incalzi R, Pedone C, Scarlata S, Battaglia $S$, Scichilone N, Forestiere $F$, et al. Correlates of mortality in elderly COPD patients: focus on health-related quality of life. Respirology 2009;14:98-104.

21. Domingo-Salvany $A$, Lamarca $R$, Ferrer $M$, GarciaAymerich J, Alonso J, Félez M, et al. Health-related quality of life and mortality in male patients with chronic obstructive pulmonary disease. Am / Respir Crit Care Med 2002;166:680-5.

22. Pelegrino NR, Lucheta PA, Sanchez FF, Faganello MM, Ferrari $R$, de Godoy I. Influence of lean body mass on cardiopulmonary repercussions during the six-minute walk test in patients with COPD. I Bras Pneumol 2009;35:20-6.

23. The COPD-X Plan. Australian and New Zealand guidelines for the management of chronic obstructice pulmonary disease 2017. Version 2.49. http://copdx.org.au/. Accessed 15 June 2017.
24. Candemir I, Kaymaz D, Ergun P, Demir N, Egesel N, Sengul F. Assessment of pulmonary rehabilitation efficacy in chronic obstructive pulmonary disease patients using the chronic obstructive pulmonary disease assessment test. Expert Rev Respir Med 2015;9:487-92.

25. Ijiri N, Kanazawa H, Yoshikawa T, Hirata K. Application of a new parameter in the 6-minute walk test for manifold analysis of exercise capacity in patients with COPD. Int I Chron Obstruct Pulmon Di 2014;9:1235-40.

26. Belman MJ, Brooks LR, Ross DJ, Mohsenifar Z. Variability of breathlessness measurement in patients with chronic obstructive pulmonary disease. Chest 1991;99:566-71.

27. Ong KC, Earnest A, Lu SJ. A multidimensional grading system (BODE index) as predictor of hospitalization for COPD. Chest 2005; 128:3810-6.

28. Punekar YS, Riley JH, Lloyd E, Driessen M, Singh SJ. Systematic review of the association between exercise tests and patient reported outcomes in patients with chronic obstructive pulmonary disease. Int I Chron Obstruct Pulmon Dis 2017;2487-2506.

29. Agrawal $S R$, Joshi $R$, Jain A. Correlation of severity of chronic obstructive pulmonary disease with health-related quality of life and six-minute walk test in a rural hospital of central India. Lung India 2015;32:233-40.

30. Oga T, Nishimura K, Tsukino M, Hajiro T, Ikeda A, Mishima M. Relationship between different indices of exercise capacity and clinical measures in patients with chronic obstructive pulmonary disease. Heart Lung 2002;31:37481.

31. Cote CG, Pinto-Plata V, Kasprzyk K, Dordelly LI, Celli BR. The 6-min walk distance, peak oxygen uptake, and mortality in COPD. Chest 2007;132:1778-85. 